\title{
粗い面の接触および摩擦すべり過程の視覚化と定量化
}

\author{
横浜市立大学大学院総合理学研究科* 岩 佐 幸 治 \\ 横浜市立大学理学部** 吉 岡 直 人
}

\section{Visualization and Quantification of Contact and Frictional Sliding Process of Rough Surfaces}

\author{
Koji IwasA \\ Graduate School of Integrated Science, Yokohama City University, Seto 22-2, \\ Kanazawa-ku, Yokohama 236, Japan \\ Naoto YoshiokA \\ Faculty of Science, Yokohama City University, Seto 22-2, \\ Kanazawa-ku, Yokohama 236, Japan \\ (Received September 25, 1995; Accepted May 1, 1996)
}

\begin{abstract}
It is known that the real area of contact is much less than nominal contact area when rough surfaces come into contact. The fact that in general we can not directly observe real contacts makes the contact problem difficult in intuitive recognition. Computer simulation is one of the ways that enable us to observe the contact spots directly on a computer display. Using three-dimensional topographies, a computer simulation was performed to see how the real area of contact changes when a contacting surface moves over the other. We can see each contact spot being created, growing and being eliminated with increasing horizontal relative displacement. The animation provides a basic recognition of changing contact spots with increasing displacement. We applied the animation to the interpretation of $D_{c}$ in the so-called rate and state variable friction law. The result shows that $D_{c}$ is the displacement required for a complete replacement of real contact area that existed at the moment of step change in slip rate. The computer simulation is a powerful means in investigating the physical process of friction.
\end{abstract}

Key words: Computer simulation, Real area of contact, Contact spot, $D_{c}$, Friction.

\section{§1. はじめに}

地震は岩盤中の断層に沿って, 両側の岩盤がずれるこ とによって引き起こされると理解されている.このこと から, 地震発生のメカニズムを解明するために, 多くの 岩石破壊や摩擦の実験が行われてきた [例えば, BRACE and Byerlee (1966), Dieterich (1979), Ohnaka et al. (1986), Ruina (1983)]。これらの実験により，例えばス ティック・スリップと地震発生機構との類似性, 摩擦力 のすべり速度依存性，主破壊の前における破壊震源核の 存在とその形成過程など, 多くの新しい知見があたらさ れた.これらの現象をより樑く理解するためには, ミク

*. ** $\bar{\top} 236$ 横浜市金沢区瀬戸 $22-2$
ロな観点からの解明 [例えば，MATsu'URA et al. (1992)] が不可欠である.

摩擦すべり現象をミクロな観点から解明するには，す べり面には顕著な凹凸があり，お互いの面はその凸部で 接触していることを考虑しなければならない，HoLM (1946) の真実接触面積の概念の登場により, 粗い面どう しが重なり合ってできる真実接触部分は，見かけの接触 面積に比べて極めて小さいことが明らかにされた，そし て，ガウジなど介在物のない乾燥した面の接触の場合に は, そのような小さな接触点における力学の総和が, マ クロな現象としての摩擦などを支配していることが明ら かにされてきた。しかしながら，このミクロな接触状態 を直接観察できないことが, 摩擦を研究する上での妨げ 
の一つとなっている.

この難点を克服するために，これまで様々な試みが行 われてきた.たとえば, 電気伝導度の測定 [HoLM (1946)], 透過波動の測定 [PYRAK-NolTE et al. (1990), YosHIOKA and KIKUCHI (1993)] がある.これらは, 真実 接触面積の変化をそれぞれ電気抵抗值や透過波動の振幅 の変化によって見るあのである．また，腐食液による真 実接触部の測定 [久門 (1969)]，温度に反応して色が変 化する染料による真実接触部の测定 [LoGAN and TUEFEL (1986)], ウッド合金を用いた真実接触部の測定 [NoLTE et al. (1989)] などあある.このように, 主に間接 的な方法によって接触面の挙動が観測されてきた. 前者 2 つは，接触中にリアルタイムで観測できるが，接触部 を直接観察することができない. 一方後者 3 つは, 実験 終了後に真実接触部分を観察することができるが，リア ルタイムで観測できないなどの欠点がある. DIETERICH and KILGORE (1994) は, 高感度のモノクロビデオカメ ラやシリコンフォトダイオードを使って, 面がすべって いる間の真実接触部の変化を直接観察した. しかし当然 のことながら, 直接観察は透明な試料に限られる.

接触部の状態やその変化を調べるもう一つの方法は, コンピュータ・シミュレーションであろう.コンピュー タ・シミュレーションは, 適当な物性值を自在に仮定す ることができる有益な手段である. シミュレーションを 行う場合の接触モデルは, GREENWOOD and WILLIAMSON (1966) によって最初に考えられた。 そして，これ以 後様々な接触モデル [BROWN and ScHOLZ (1985), YAMADA et al. (1978b), YoshiokA and Scholz (1989a, b)] が提唱されてきた. また接触モデルの発展と同時に, 表面の形状をいかに正確に把握するかという問題も重要 となる. 表面の形状を正確に測定するには，3 次元的に データを採取すればよいのであるが，採取するのには多 大の時間を要することと, データ量が膨大になることな どの理由から，2 次元プロファイルから統計的な方法な どを用いて, 3 次元的な表面の統計量を予测する方法 (3 次元マッピング）が開発された [ADLER and FIRMAN (1981), Nayak (1971), Sayles and Thomas (1979), YAMADA et al. (1978a)]. シミュレーションにおいては 通常, 3 次元マッピングによって得られた統計量が用い られることが多い.
YosHiokA (1994a，b) は，3 次元表面形状の測定デー 夕を直接用いて, 粗い面どうしの接触のシミュレーショ ンを行い, 法線応力下の粗い面の挙動を予測した.

本論は, YoshiokA (1994a) の方法を応用して, 法線応 力下における接触の状態, および面が水平移動する間の 接触状態の変化を視覚的に捉えること，そしてこの状態 を定量的に把握することを目的とする. また，上記のこ とを通して経験的に知られている摩擦構成則の物理的意 味を探ることが目的である.

\section{§2. コンピュータ・シミュレーション}

\subsection{3 次元表面形状データ}

シミュレーションに用いる表面形状データは, 研磨材 で磨いた真鍮の表面を，触針法による 3 次元表面形状測 定器 (小坂研究所製, 三次元表面粗さ測定器, SE-30K) で測定したものである. $5 \mu \mathrm{m}$ 間隔の格子状に $512 \times$ 512 点, 約 25 万点のデータを採取した（データ採取の 方法やフィルター処理に関しては, YoshioKA (1994a) を参照されたい). 3 次元表面形状データの一部分の鳥 瞰図を Fig. 1 に示す. 表面の粗さは 2 種類である. \#320

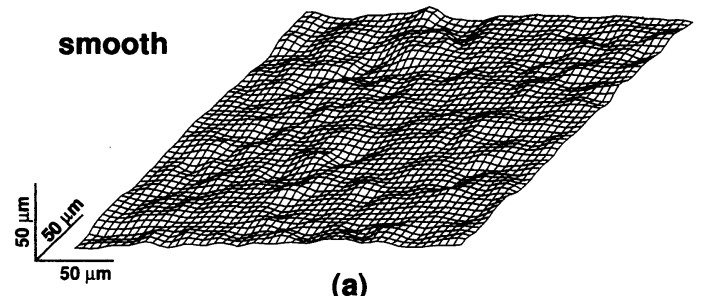

(a)

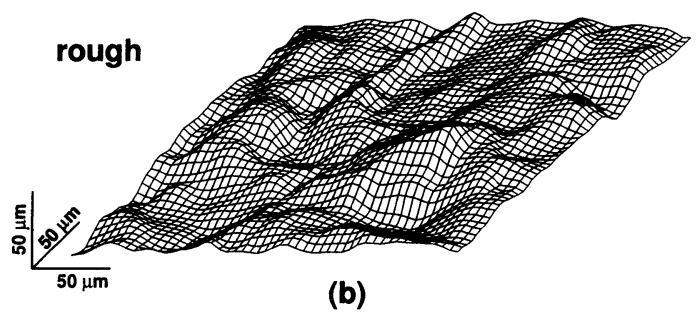

Fig. 1. Perspective views of $50 \times 50$ point positions of the $512 \times 512$ point surfaces. These data were taken with a stylus profilometer on a brass surface handground with abrasives. (a) Smooth surface, and (b) rough surface.

Table 1. Surface topographic parameters.

\begin{tabular}{c|c|c|c}
\hline \hline Surface & Roughness, $\mu \mathrm{m}$ & Radius, $\mu \mathrm{m}$ & Summit density, $\times 10^{4} \mathrm{~cm}^{-2}$ \\
\hline Smooth & 1.65 & 15.1 & 13.2 \\
\hline Rough & 5.70 & 11.4 & 7.3 \\
\hline
\end{tabular}




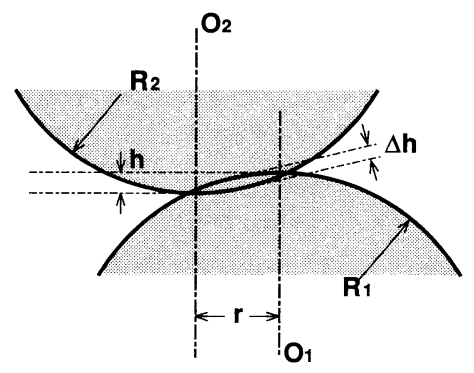

mean plane of surface 1

Fig. 2. Schematic expression of an individual asperity contact. The separation $L$ is the distance between lower and upper mean planes. The horizontal distance of the vertical center axes of the lower and the upper asperities is denoted as $r . R$ and $O$ are the radii and the centers of asperity, respectively. The subscripts 1 and 2 represent lower and upper surfaces.

の研磨材で磨いた表面を「なめらかな面 (smooth)」(Fig. 1a), \#120 の研磨材で磨いた表面を「粗い面 (rough)」 (Fig. 1b) と呼ぶことにする. それぞれの表面の粗さを rms 粗さ (高さ分布の標準偏差) で表すと, なめらかな 面は $1.65 \mu \mathrm{m}$, 粗い面は $5.70 \mu \mathrm{m}$ である. 粗い面はなめ らかな面の 3.5 倍の粗さである.

採取した 3 次元表面形状データにおいて, 格子上のあ る 1 点が周りの 8 点よりあ高いときにこれをアスペリ ティ（突起）とみなした. 各々のアスペリティの頂点付 近は球面で近似できると仮定し，これら 9 点を用いた球 面の最小二乗法によって個々のアスペリティの頂点座標 および曲率半径を求めた. このようにして求めた表面形 状パラメータを Table 1 に示す. 曲率半径 (radius) は全 アスペリティについての平均值である。 また, アスペリ ティの面密度 (summit density) は, 単位面積あたりの アスペリティの数である. 曲率半径の平均値は粗い面の 方がなめらかな面よりあ小さい. つまり，粗い面はなめ らかな面よりあ先が尖った険しい形状であることを示し ている. また, なめらかな面のアスペリティの面密度は 粗い面の約 2 倍であり, 表面が接触した場合に粗い面よ りあ多くの接触点ができることが予想される.

\section{2 接触モデル}

今回のシミュレーションでは, 接触による変形は Hertz の弾性接触理論 [例えば, Timoshenko and GooDIER (1951)] に基づいて行った. すなわち, アスペリティ の接触を 2 つ弾性球の接触としてモデル化する. Fig. 2 にこのモデルの模式図を示す.
接触は，次式で定義される上面と下面のアスペリティ の食い込み量 $\Delta h$ が正のときに起こる.すなわち,

$$
\Delta h \simeq h-\frac{r^{2}}{2\left(R_{1}+R_{2}\right)}>0\left(h, \Delta h \ll R_{1}+R_{2}\right)
$$

ここで, $h$ は接触するアスペリティの鉛直方向のオー バーラップ量, $r$ はお互いのアスペリティの鉛直中心座 標軸 ( $z$ 軸) 間の水平距離, $R_{1}$ と $R_{2}$ はアスペリティの先 端曲率半径である (Fig. 2 参照). アスペリティどうしの 接触が起こったときに，その接触点にかかる局所法線力 (Fig. 2 の $O_{1}-O_{2}$ 方向) $\Delta w$ は, 次式で計算される.

$$
\Delta w=\frac{4}{3} E^{\prime} R_{r}^{1 / 2} \Delta h^{3 / 2}
$$

ここで, $E^{\prime}$ と $R_{r}$ は, $E$ をヤング率, レをポアソン比とし $\tau$

$$
\begin{aligned}
& \frac{1}{E^{\prime}}=\frac{1-\nu_{1}^{2}}{E_{1}}+\frac{1-\nu_{2}^{2}}{E_{2}} \\
& \frac{1}{R_{r}}=\frac{1}{R_{1}}+\frac{1}{R_{2}}
\end{aligned}
$$

で定義される．添え字の 1 と 2 は，それぞれ下面と上面 を示している. また, 局所接触面積 $\Delta s$ は次式で計算さ れる.

$$
\Delta s=\pi R_{r} \Delta h
$$

シミュレーションでは, 我々の興味の対象が岩石である ことから，上下面ともに $E=50 \mathrm{GPa}, \nu=0.25$ を仮定し た.

\section{3 シミュレーションの方法}

シミュレーションは, 前述の面をコンピュータ上で仮 想的に重ね合わせ, 一方の面を他方に対して水平移動さ せながら必要な量を計算するという方法をとった，上面 は，下面を裏返しにしたあのである，すなわち，上と下

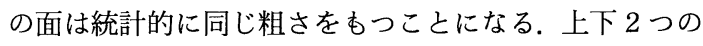
表面の基準面（平均高さ0）の間隔 (separation) を一定 に保ちながら, 下面を固定して上面を $1 \mu \mathrm{m}$ ずつ水平移 動させる. 最大の変位量は $100 \mu \mathrm{m}$ である.これは後で 見るように，ミクロな接触が生成されてからやがて消滅 するまでの距離に比べて十分長い変位量である. 各変位 ごとに，下面のそれぞれのアスペリティが上面のアスペ リティと接触するかどうかを (1) 式で判断し, $\Delta h$ が正の ときに (2) 式と (5) 式を用いて, 個々の接触点について の局所法線力や接触面積を計算した. 全体の法線応力 は,このようにしてそれぞれの接触点について計算した 局所法線力の総和を見かけの接触面積で除算したもので ある.

各変位ごとに得られた真実接触部の様子を 1 コマず つ画像ファイルに保存し, その画像ファイルを画像ロー ダーでコマ送りにすることによって, 動画的な接触点の 
$10 \mathrm{MPa}$

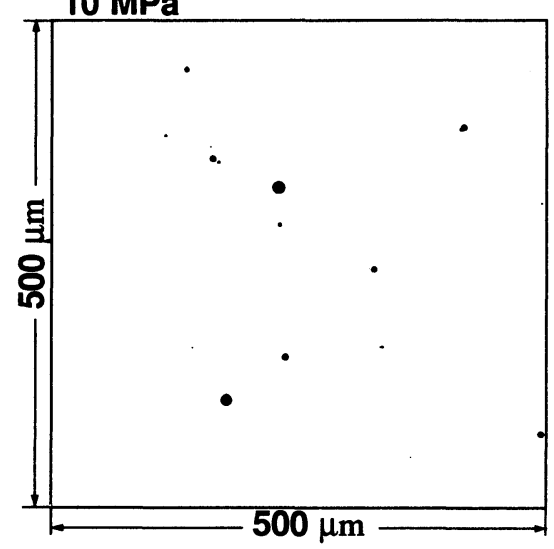

$30 \mathrm{MPa}$

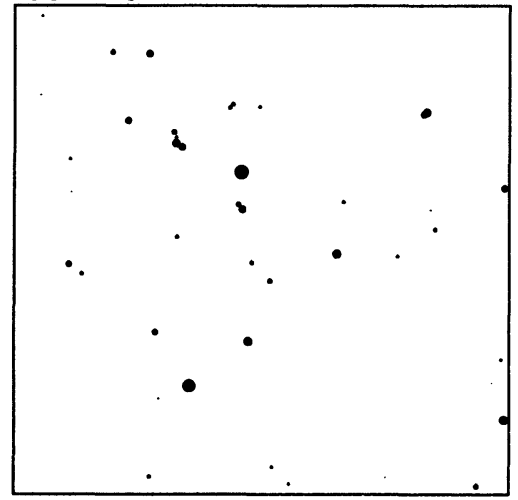

$20 \mathrm{MPa}$

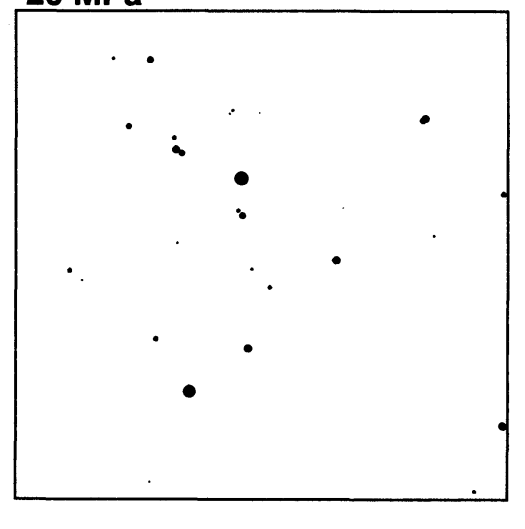

$40 \mathrm{MPa}$

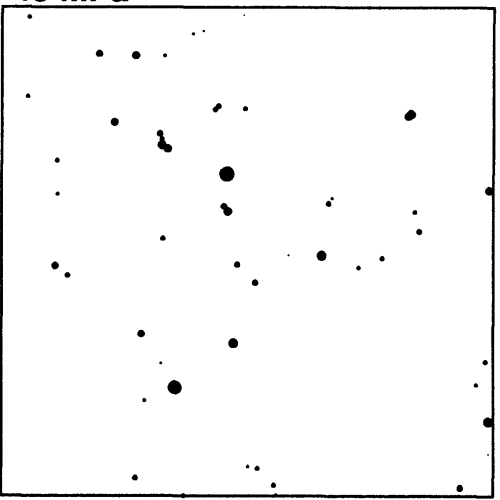

Fig. 3. Growth of real area of contact with increasing normal stress from $10 \mathrm{MPa}$ to $40 \mathrm{MPa}$ (smooth surface). The black points represent the real contact area.

変化を追跡することができる.

\section{§ 3 結果}

\section{1 法線応力下での接触点の状態}

Fig. 3 に法線応力の增加にともなう真実接触部の変化 を示す.これはなめらかな面について, 法線応力を 10 $\mathrm{MPa}$ 間隔に $40 \mathrm{MPa}$ まで変化させたときの接触の状態 を示している．黑い点が真実接触部を示している．真実 接触部がまばらに点在している様子を見ることができ る. 法線応力が増加すると, 新しく接触点が生まれてく る様子や，これまで存在した接触点が大きくなる様子を 見ることができる. しかし, 個々の接触面積の增大は, ある程度以上大きいあのについては法線応力の増加によ る変化が小さく, 目で確かめるのが難しい. 法線応力が $30 \mathrm{MPa}$ のとに, 真実接触面積は見かけの接触面積に 比べてわずか $0.5 \%$ である.

接触点の面積および直径の分布をそれぞれ Fig. 4 と Fig. 5 に示す. 5, 15, および $30 \mathrm{MPa}$ の法線応力におけ る結果を同時に示した. 面積の分布が指数分布的である
のに対して, 直径の分布はガンマ分布的である. 両方と あ接触点の大きさの分布を示しているにあかかわらず, 分布の形が大きく異なるのは一見不可解に思われる. し かし統計理論によると, 面積 $s$ の確率密度関数 $f_{s}$ が $f_{s}(s)$ $=a \exp (-\alpha s)$ で与えられたとき, 面積は直径 $l$ の 2 乗 に比例するので $s=\beta l^{2}$ とおくと, 直径の確率密度関数 $f_{l}$ は,

$$
\begin{aligned}
f_{l}(l) & =f_{s}\left(\beta l^{2}\right) \cdot \frac{d}{d l}\left(\beta l^{2}\right) \\
& =a \mathrm{e}^{-\alpha \beta l^{2}} \cdot 2 \beta l
\end{aligned}
$$

で与えられ, ガンマ分布的になる. 直径の平均値は, な めらかな面で約 $5 \mu \mathrm{m}$, 粗い面で約 $8 \mu \mathrm{m}$ である.ここで 特徴的なことは, 法線応力が变化しても面積および直径 の分布はほとんど変化しないということである。これは Fig. 3 に示したように, 法線応力の増加に対する真実接 触面積の増加は, これまで接触していたものの面積が大 きくなることにあよるが, むしろ多くの新しい小さな接 触点が生まれることが大きく影響している．このために 全体的な分布としては法線応力にほとんど影響されない のである. ただし, 真実接触面積そのものは法線応力と 


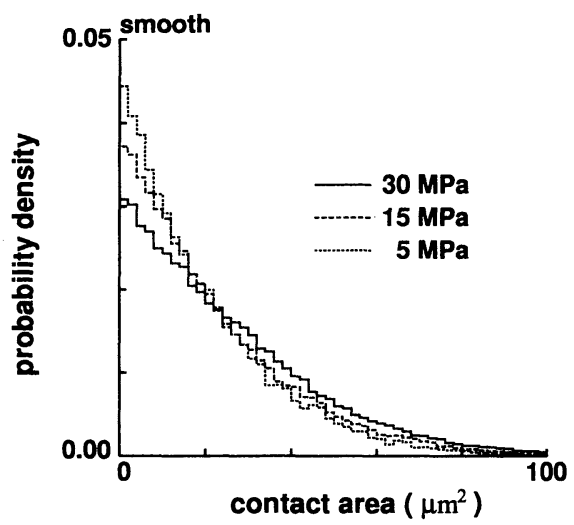

(a)

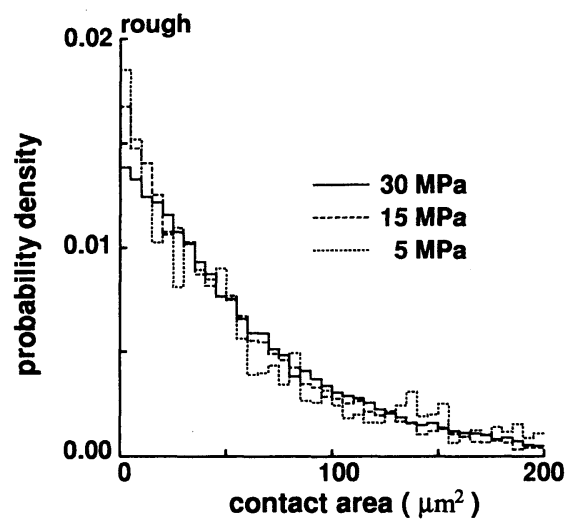

(b)

Fig. 4. Distribution of contact area. The solid, dashed, and dotted lines represent the distributions under 30, 15, and $5 \mathrm{MPa}$ normal stresses, respectively. (a) Smooth surface, and (b) rough surface.

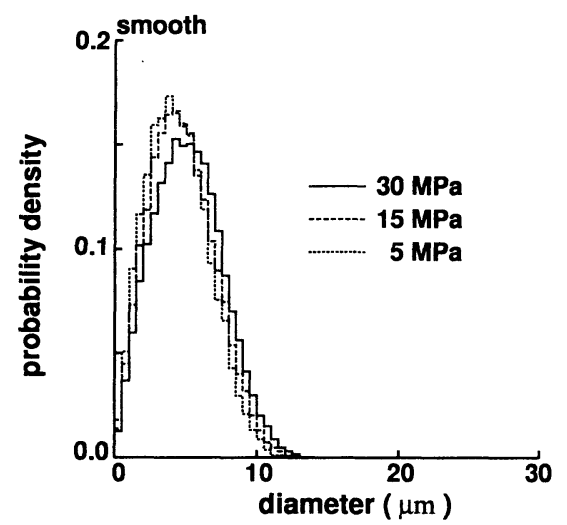

(a)

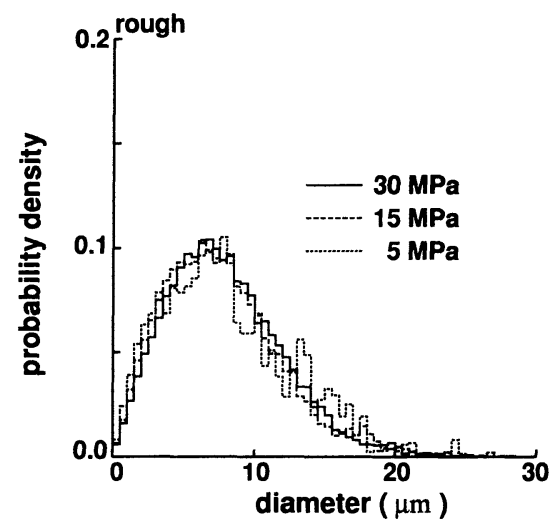

(b)

Fig. 5. Distribution of contact diameter. The solid, dashed, and dotted lines represent the distributions under 30,15, and $5 \mathrm{MPa}$ normal stresses, respectively. (a) Smooth surface, and (b) rough surface.

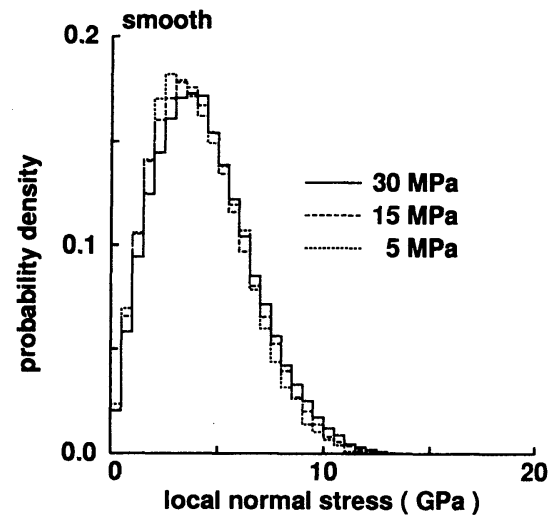

(a)

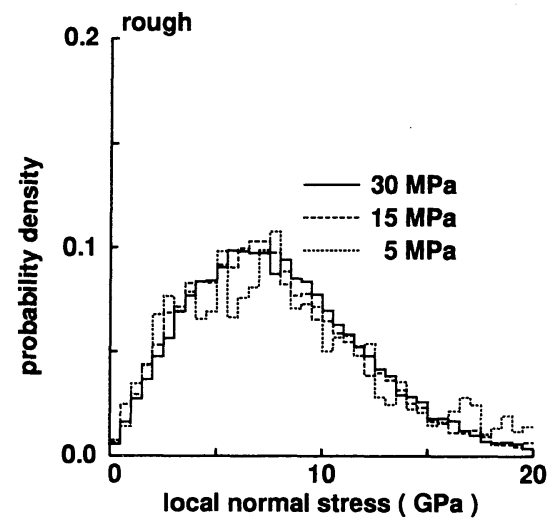

(b)

Fig. 6. Distribution of local normal stress. The solid, dashed, and dotted lines represent the distributions under 30,15 , and $5 \mathrm{MPa}$ normal stresses, respectively. (a) Smooth surface, and (b) rough surface. 


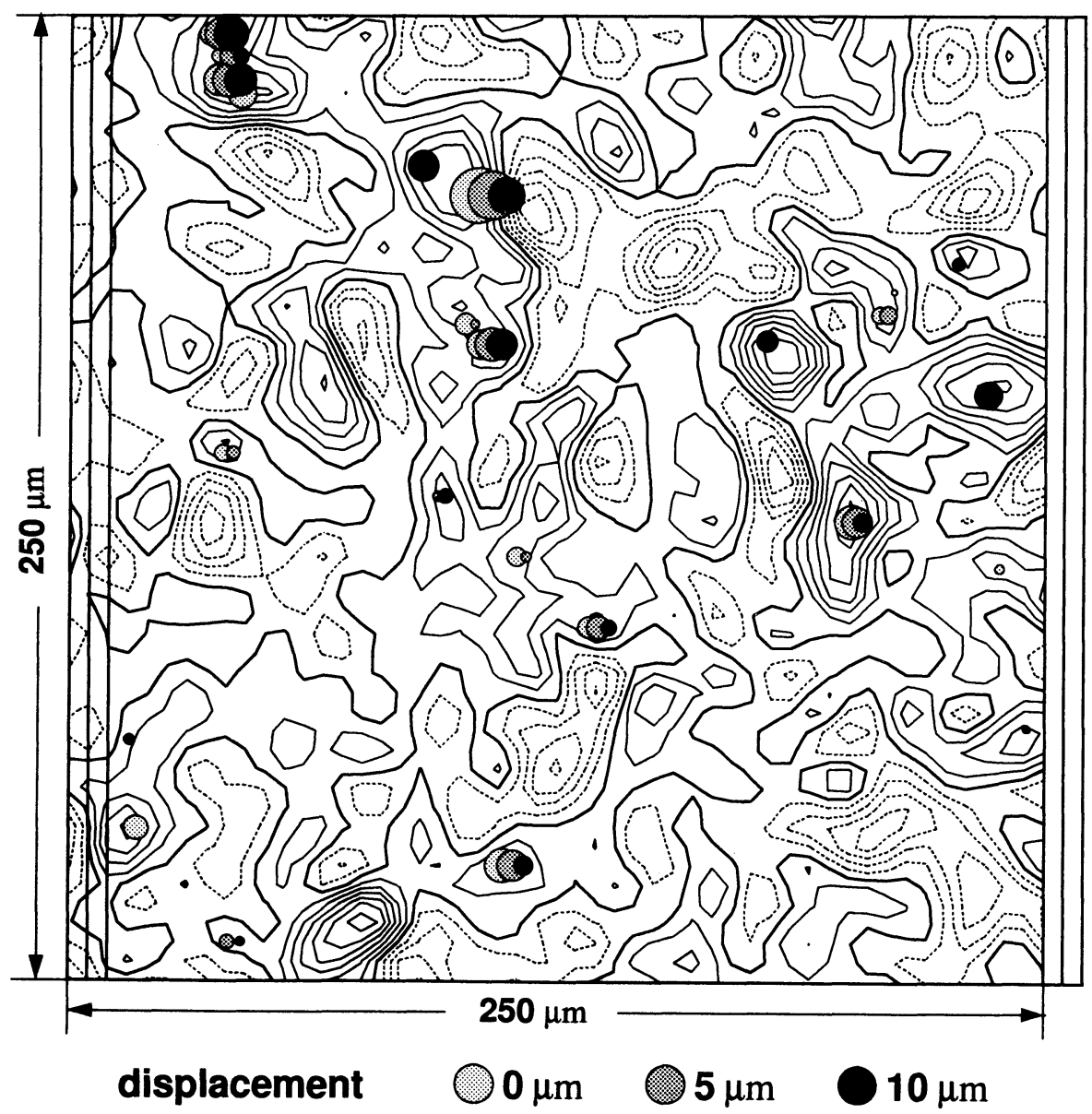

Fig. 7. Change in contact spots with horizontal displacement. The upper surface moves from left to right. The thick lines are the contours of zero height of the lower surface. The thin solid and dotted lines represent positive and negative contours with a vertical interval of $1 \mu \mathrm{m}$, respectively. The real contact spots are shown by circles with different gray scales corresponding to 0,5 and $10 \mu \mathrm{m}$ displacement as indicated in the figure. At some asperity contacts, it is seen that the location and the magnitude of contact spots vary with displacement.

きわめてよい比例関係にある [YoshioKA (1994a)].

わずかな接触面積で面を支えているために，（見かけ の）法線応力に比べて個々の接触点には，極めて大きな 局所法線応力 (local normal stress) がかかっている.

Fig. 6 に個々の接触点にかかる局所法線応力の分布を示 す. 平均值は, なめらかな面で約 $4 \mathrm{GPa}$, 粗い面で約 8 $\mathrm{GPa}$ と見かけの法線応力に比べて接触点には 2〜3析大 きな応力がかかっている.この分布あガンマ分布的であ り, 直径の分布と同様に法線応力にはほとんど影響され ない.

\section{2 水平移動時の接触点の状態の変化}

Fig. 7 に面を重ねて上面を水平移動させたときの接触 点の変化の一例を示す.これは, なめらかな面について separation $5 \mu \mathrm{m}$ で一定に保ちながら（法線応力は約
$30 \mathrm{MPa}$ )，下面を固定して上面を右へ移動させたときの 接触点の変化を示したものである，図の外枠は上面の変 位量 0,5 および $10 \mu \mathrm{m}$ を示している. また, 図中の等高 線は下面の凹凸を示すあので，等高線間隔は $1 \mu \mathrm{m}$ であ る. 実線が基準面より高いところを示し，点線は基準面 より低いところを示している（図には上面の等高線を示 していない. 上面にも同様の粗さの面が右に移動してい ることに注意). 接触点は大きさを変えながら移動して, あるところでは新しく生まれ，あるところでは前にあっ たものが消えているなど, 接触点の変化の過程を見るこ とができる.このような接触点の変化から，接触点が生 まれてから消えるまでに上面が動いた距離（生存距離, life distance) を調べた. Fig. 8 に生存距離の分布を示 す.この分布もガンマ分布的である. また，直径の分布 


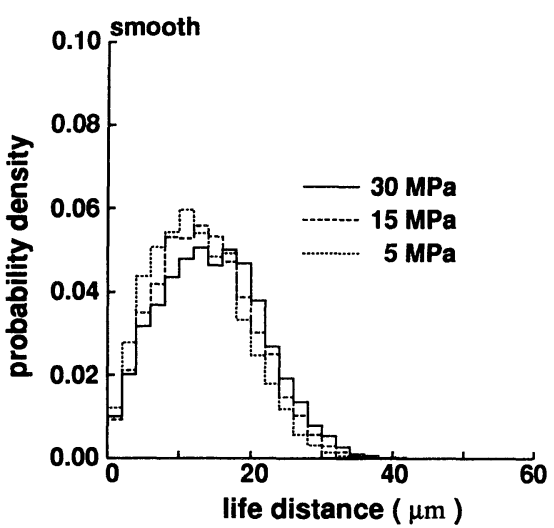

(a)

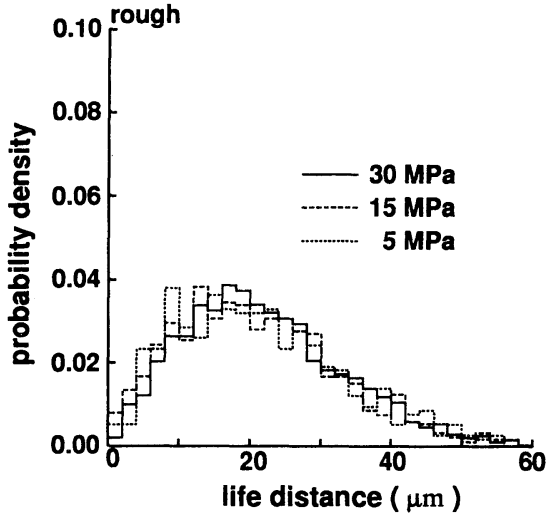

(b)

Fig. 8. Distribution of life distance. The solid, dashed, and dotted lines represent the distributions under 30,15 , and $5 \mathrm{MPa}$ normal stresses, respectively. (a) Smooth surface, and (b) rough surface.

(a)
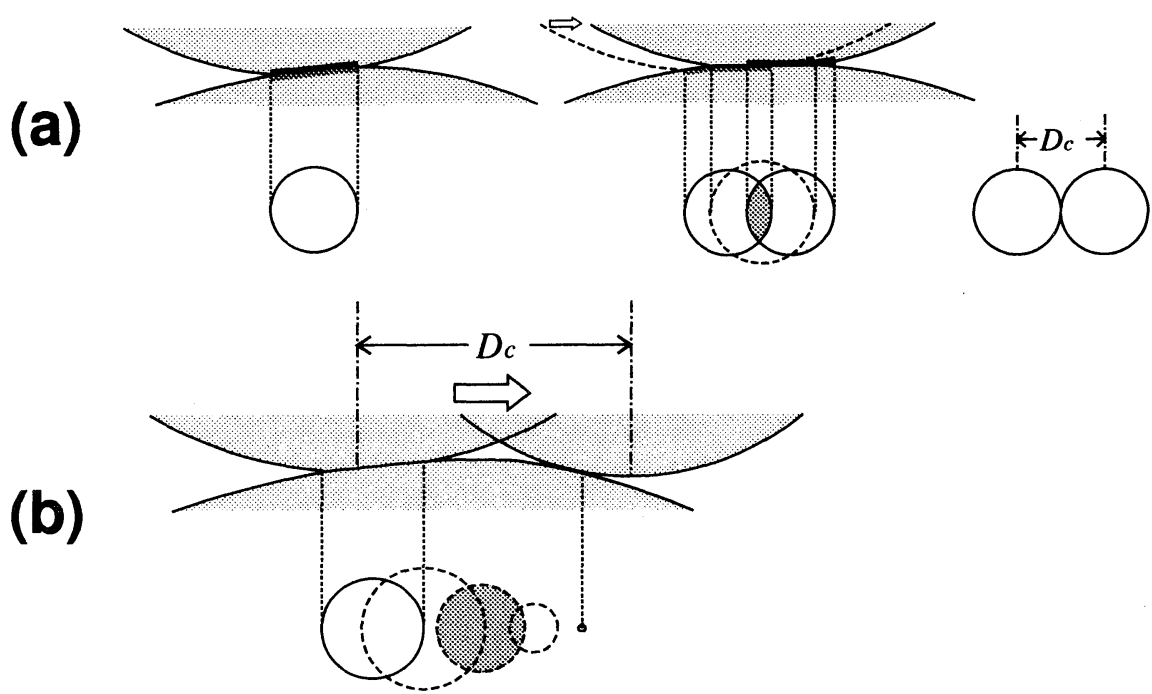

Fig. 9. Schematic expression of two interpretations of $D_{c}$. (a) Interpretation (1): Two asperities form a contact (left). As the displacement is increased, the overlapped area (hatched) decreases (center). $D_{c}$ is the displacement over which the overlapped area disappears (right). (b) Interpretation (2): The contact (solid circles) existing at the moment of change in slip rate moves to right, changes the size (dashed circles), and finally disappears. Thus $D_{c}$ is the displacement over which the upper surface moves until the contact existing at the moment of change in slip rate disappears.

と同じように，法線応力にはほとんど依存しない. 生存 距離の平均值は, なめらかな面で約 $14 \mu \mathrm{m}$, 粗い面で約 $20 \mu \mathrm{m}$ と粗い面の方が大きい. 生存距離は表面粗さに大 きく依存する。これは, 粗い面はなめらかな面よりあ波 長の大きなアスペリティが多数あるためである.

\section{3 特幑的なすべり距離, $D_{c}$}

水平移動のシミュレーションを利用して, rate and state variable friction law [DIETERICH (1979, 1981), RUINA (1983)] に現れるパラメータを，ミクロな観点か らその意味を探ってみよう。 上記構成則は, すべり速度
をステップ状に変化させる岩石実験の結果から導かれた あのである. 同構成則に現れるパラメータの 1 つである 「特徴的なすべり距離, $D_{c} 」$ は, すべり速度がステップ状 に変化した後に摩擦力が新たな定常状態に落ちつくまで の変位量をいう（ $D_{c}$ という表記は, slip weakening law [OHNAKA et al. (1986)] においては臨界すべり変位 量として用いられているが, ここで言う $D_{c}$ は, 上述の通 り，すべり速度をステップ状に変化させる実験におい て, すべり速度が変化した後に摩擦力が新たな定常状態 に落ちつくまでの変位量を差している.） $D_{c}$ はすべり速 


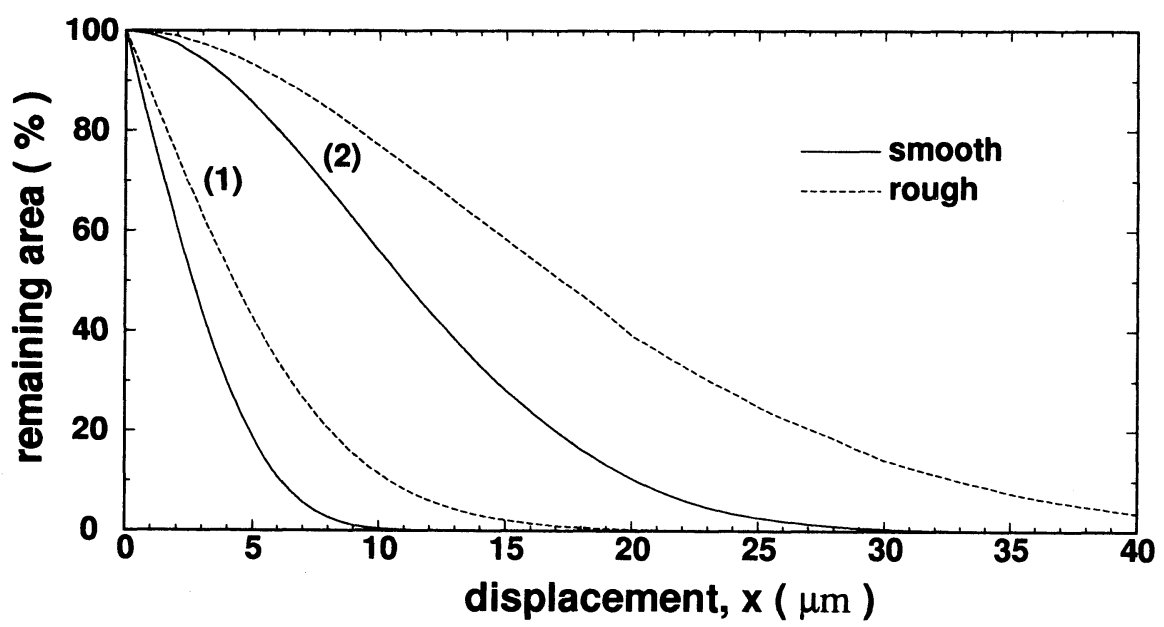

Fig. 10. Change in the remaining contact area with horizontal displacement for the interpretations (1) and (2). Normal stress is about $30 \mathrm{MPa}$. The solid and dashed lines represent smooth and rough surfaces, respectively. The surface roughness much affects $D_{c}$.

度, 法線応力にほとんざ依存せず, 表面粗さに依存する ことが実験的に明らかにされている [DIETERICH (1979)]. このことから DIETERICH (1979) は $D_{c}$ を「すべり速度が 变化する直前の接触が完全に新しい接触に置きかわるの に必要な変位量」と解釈した. ところで「接触の置きか わり」とは何を意味しているのだろうか.これには少な くとむ 2 つの解釈が可能であろう. RABINOwICZ (1956) は, 様々な大きさの結合部が変位とともにランダムに形 成され, それぞれの結合部はその直径分の水平変位が与 えられると消滅するというモデルを考えた．ある変位の 摩擦力は, それぞれの結合部におけるせん断強度の総和 として表される.この摩擦力は变位とともに周期的に変 動して, その変動の特徴的な距離が, 接触結合部の平均 直径に大体等しくなる.つまり,この種の解釈に従うと, $D_{c}$ はすべり速度が变化する瞬間にあった結合部 (junction) が消えるまでの距離と言える. 一方, Fig. 7 に示さ れているような生存距離タイプの「接触の置きかわり」 によると, $D_{c}$ は現在の接触点がすべて消滅し, すべてが 新しい接触に置きかわるまでの距離, と言える. それぞ れの解釈を整理すると， $D_{c}$ とは，(1)すべり速度が変化 する瞬間（变位 0) に上下面共通に接触していた部分に ペンキを塗り, ペンキを塗った部分の共通接触部分が完 全に消滅するまでの变位量 (Fig. 9(a)), (2) すべり速度が 变化する瞬間 (变位 0) に存在した接触点が, Fig. 7 に示 したような変化をたどりながら移動して完全に消滅する までの変位量 (Fig. 9(b))，ということになる．これらの 解釈について, RUINA (1983)のいう「状態 (state)」につ いて考えてみると，Fig. 9 の灰色部分に「状態」が記憶 されているとみなすことができる.すすなわち, (1)の解釈
ではすべり速度が変化した瞬間に接触していた上下面共 通の部分であり，(2) は移動し続ける接触点そのものが 記憶していることになる. 言いかえると，(2)の場合は接 触しているアスペリティが状態を記憶していると考える こともできる. 上記 $2 つ$ 解釈について, 変位 0 のと き,すなわち速度変化があった瞬間の接触部分（状態を 記憶していると思われる面積）の上面の水平変位に対す る変化を計算した. Fig. 10 に結果を示す. 法線応力は約 $30 \mathrm{MPa}$ である. 変位 0 の出発点を変えて 10 回繰り返 し行った平均が示されている. $D_{c}$ については, 摩擦力が $1 / e$ に落ちるまでの変位を定義とする論文が多い，しか し, DieTERICH (1979) の結果をよく検討したところ, 摩 擦力がほぼ定常状態に落ちつくまでの変位量を採用して いるようである.よってここでは, 変位 0 のときの接触 面積が $1 \%$ に減少する変位を $D_{c}$ とした. $D_{c}$ は粗い面の 方が大きく, 表面粗さに大きく依存する. また，(1)の解 釈による結果は指数関数的に減少しているのに対し, (2) の解釈による結果は，(1)に比べてなだらかに減少する. これは, 多くの接触点の中には接触面積が変位ととあに 大きくなるあのと小さくなるあのがあり, 両者のバラン スによって平均化されるためである.

同様のシミュレーションを今度は法線応力を半分（約 $15 \mathrm{MPa}$ ）に変えて行った. なめらかな面についての結 果を Fig. 11 に示す. 法線応力を半分にしたにあかかわ らず，どちらの解釈においてあ，グラフの軌跡はほとん ど変化していない，すなわち， $D_{c}$ は法線応力にほとんど 依存しない.これは, 接触点の大きさの分布 (Fig. 4, Fig. 5) が法線応力にほとんど依存しないことに対応してい る. 接触直径, 局所法線応力, 生存距離の分布が, 法線 


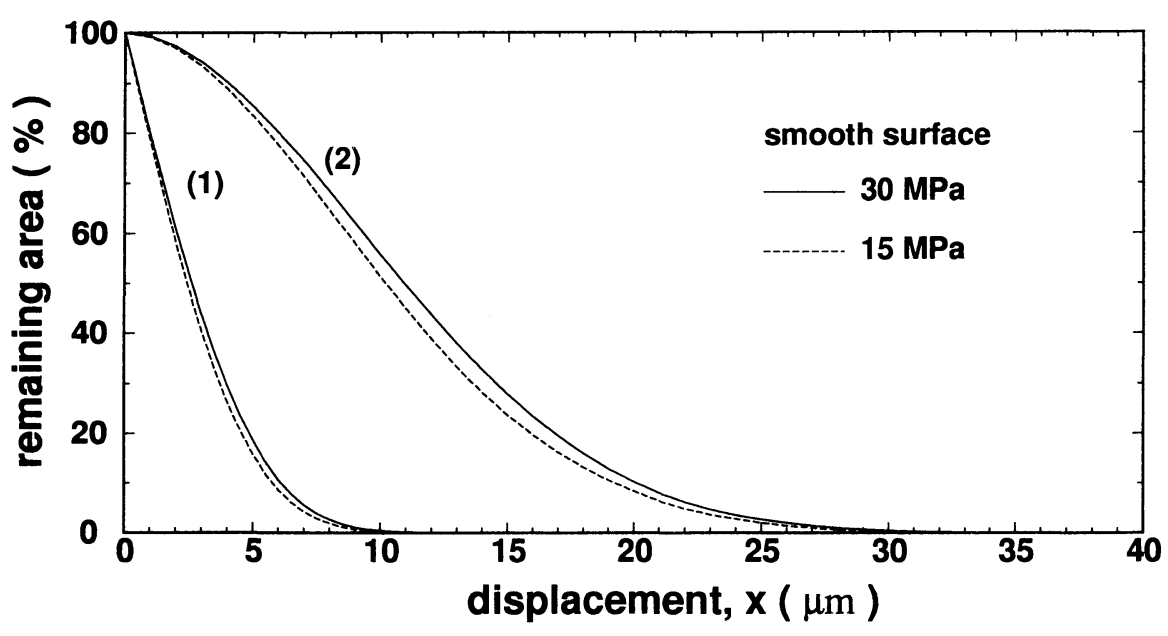

Fig. 11. Effect of normal stress on $D_{c}$ for the smooth surface. The solid and dashed lines represent the results under $30 \mathrm{MPa}$ and $15 \mathrm{MPa}$ normal stress, respectively. The whole shape of the curves is not largely changed by the normal stress.

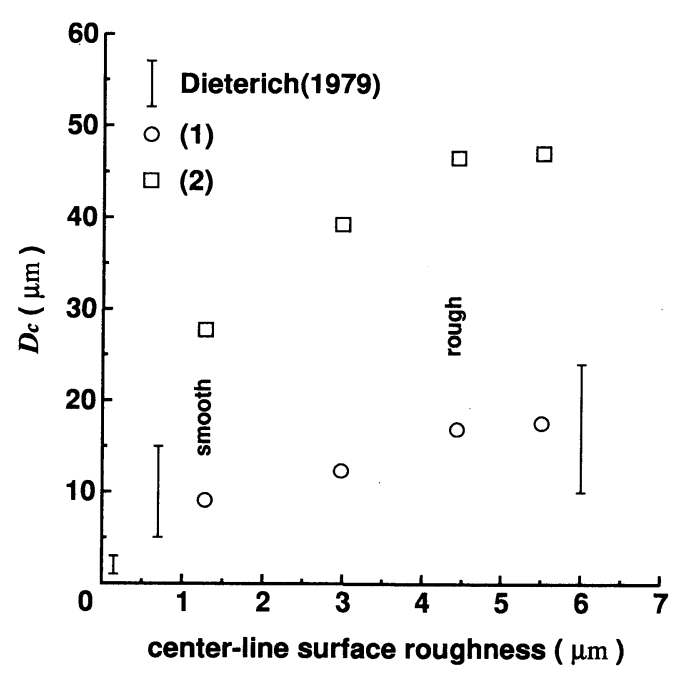

Fig. 12. Comparison of the results of the simulation with DieTERICH's (1979) experimental observations. The bars are from DieteRICH (1979). The circles and squares are calculated by the interpretations (1) and (2), respectively. The interpretation (1) well agrees with the experimental observation.

応力にほとんど依存しないことを思い出してほしい (Fig. 5, Fig. 6 と Fig. 8 参照).

シミュレーションで得られた結果をDIETERICH (1979) の $D_{c}$ と表面粗さについての実験結果 (Table 2) と比較した。比較結果を Fig. 12 に示す. DIETERICH (1979) の結果 (棒線) は, 表面粗さが中心線平均粗さで 示されているため, シミュレーションに用いた面の粗さ あそれに合わせて示した。（1）の解釈による結果は DIE-
Table 2. Experimental results [after Dieterich (1979)].

\begin{tabular}{ccc}
\hline \hline Surface & Roughness, $\mu \mathrm{m}$ & $D_{c}, \mu \mathrm{m}$ \\
\hline$\# 60$ & 6.0 & $10-24$ \\
$\# 240$ & 0.7 & $5-15$ \\
$\# 600$ & 0.15 & $1-3$ \\
\hline
\end{tabular}

TERICH (1979) の結果の空いている中間部分を埋めるよ うにしてよく一致する．この(1) の解釈がよく一致する という結果は, ある瞬間の接触状態のビデオイメージか ら (1) の解釈と同等のシミュレーションを行った DIETERICH and KILGORE (1994) の結果と調和的である.「接 触の置きかわり」という語彙からの直感的なイメージ は, Fig. 7 に見たような生存距離タイプをまず想起させ る.しかし, 結果は「速度が変化した瞬間における接触 部分の置きかわり」を示唆するものである.

Dieterich and KiLGORE (1994) によると， $D_{c}$ は接触 点の直径の平均值に近いと述べられているが, 面積が $1 \%$ に減少するまでの変位を採用した我々の結果は, 直 径の平均值の約 2 倍となった．この違いは, 彼らの実験 では試料であるアクリルやガラスが塑性変形していたこ とによるあのと考えられる.

\section{§4. 議論}

接触している面の相互作用は, 見かけの接触面積に対 して極めて小さい真実接触面積を通して行われるため に, 接触点に関係する統計量が重要になる，そのような 統計量を算出, そして処理するという点では, シミュ レーションは非常に有効な手段である. また，Fig. 7 に 


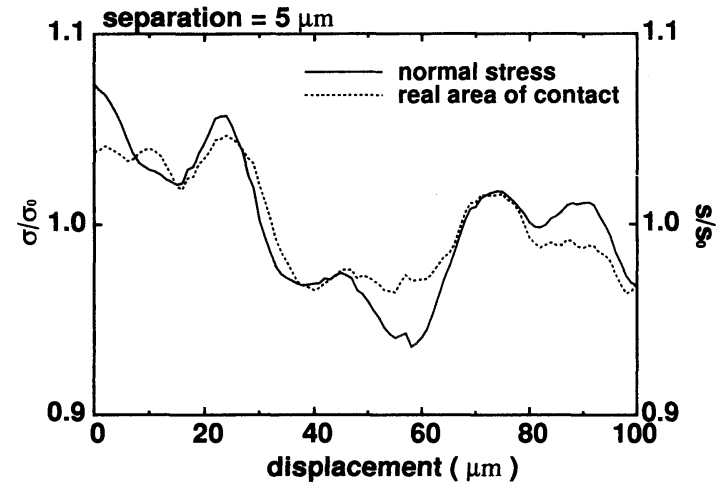

Fig. 13. Fluctuation of normal stress and real area of contact of smooth surface with increasing horizontal displacement at the separation of $5 \mu \mathrm{m}$. The vertical axes of normal stress (solid curve) and real area of contact (dashed curve) are normalized by the mean value $\sigma_{0}$ and $s_{0}$, respectively. The magnitude of the fluctuation is less than $10 \%$ of the average.

示したように, 面が水平移動している間の接触点の変化 を動画的に見ることができ，ある接触点に注目してそれ を追跡できること，そしてこれらを通して接触の状態を 直感的に把握できることは, シミュレーションの有利な 点である. そして, その利点を利用して特徴的なすべり 距離 $D_{c}$ の解釈について調べた結果は, DIETERICH and KILGORE (1994) の結果之調和的であった. このことか ら, シミュレーションは摩擦構成則に現れるパラメータ の物理的意味を明らかにする一つの重要な手段になり得 る.

しかしながら, シミュレーション特有の問題点もあ る. 一つはデー夕数の問題である. 接触点の数が有限で あるために, separation を一定に保ちながら水平移動さ せたときに, 法線応力および真実接触面積に変動が見ら れた. Fig. 13 になめらかな面について, separation が $5 \mu \mathrm{m}$ のときの変位に対する法線応力および真実接触面 積の変動を示す．縦軸はそれぞれの平均值で規格化され ている. 法線応力と真実接触面積の変動は, 同様の軌跡 を描いている.これは, 法線応力が増加するとそれに よって真実接触面積が増加することに対応している．変

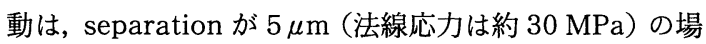
合には，平均值に対して 10\% 以下であるが， separation が大きい場合（法線応力が小さく, 接触点数が少な い場合）には，この変動量は大きくなる．このような変 動は有限の接触点を扱っている限り避けられない. 変動 をできるだけ減らすために，十分に大きな面積を用いな くてはならない，たとえば，見かけの接触面積を 4 倍に
して行ったシミュレーションでは, 法線応力の変動は約 $30 \%$, 真実接触面積の変動は約 $20 \%$ 減少した.

あう一つの問題点は取り扱うモデルである. 今回のシ ミュレーションでは, 破壊や塑性変形などは含まれてい ない. Fig. 6 に示したように，個々の接触点には非常に 大きな法線応力がかかっており，中には弾性限界を越え ているものも存在する。そそのような弾性限界を越えた接 触点が，真実接触面積の接触時間依存性などのように， 摩擦すべり過程に大きく影響してくるかもしれない．破 壊や塑性変形を含む場合，あるいはガウジを含む場合な どをモデル化し，ミクロな観点からの摩擦の解析を行う ことは今後の課題である.

\section{謝辞}

東京大学の松浦充宏氏と東北大学の加藤尚之氏には, 貴重なコメントを頂いた。ここに記して感謝いたしま。 す. 本研究は東京大学地震研究所共同研究プログラム (1995-B0-04) の援助を受けました.

\section{文献}

Adler, R. J. and D. Firman, 1981, A non-Gaussian model for random surfaces, Phil. Trans. Roy. Soc. London, A, 303, 433-462.

Brace, W. F. and J. D. Byerlee, 1966, Stick-slip as a mechanism for earthquakes, Science, 153, 990-992.

Brown, S. R. and C.H. Scholz, 1985, Closure of random elastic surfaces in contact, J. Geophys. Res., 90, 5531-5545.

Dieterich, J.H., 1979, Modeling of rock friction 1. Experimental results and constitutive equations, J. Geophys. Res., 84, 2161-2168.

Dieterich, J.H., 1981, Constitutive properties of faults with simulated gouge, in Mechanical Behavior of Crustal Rocks, AGU Geophys. Monogr., 24, 103-120.

Dieterich, J. H. and B. D. Kilgore, 1994, Direct observation of frictional contacts: New insights for state-dependent properties, Pure Appl. Geophys., 143, 283-302.

Greenwood, J. A. and J. P. B. Williamson, 1966, Contact of nominally flat surfaces, Proc. Roy. Soc. London, A, 295, 300-319.

久門輝正, 1969 , 固体仕上面間の接触機構（第 3 報, 接 触点の数とその大きさの分布), 日本機械学会論文集, 35, 880-889.

Holm, R., 1946, Electric contacts, H. Gebers Förlag.

Logan, J. M. and L. W. Teufel, 1986, The effect of normal stress on the real area of contact during frictional sliding in rocks, Pure Appl. Geophys., 124, 471-485.

Matsu'ura, M., H. Kataoka and B. Shibazaki, 1992, Slip-dependent friction law and nucleation proc- 
esses in earthquake rupture, Tectonophys., 211, $135-148$.

NAYAK, P. R., 1971, Random process model of rough surfaces, J. Lubr. Tech., 93, 398-407.

Nolte, D. D., L. J. Pyrak-Nolte and N. G. W. Cook, 1989, The fractal geometry of flow paths in natural fractures in rock and the approach to percolation, Pure Appl. Geophys., 131, 111-138.

Ohnaka, M., Y. Kuwahara, K. Yamamoto and T. Hirasawa, 1986, Dynamic breakdown processes and the generating mechanism for high-frequency elastic radiation during stick-slip instabilities, in Earthquake Source Mechanics, AGU Geophys. Monogr., 37, 13-24.

Pyrak-Nolte, L. J., L. R. Myer and N. G. W. Cook, 1990, Transmission of seismic waves across single natural fractures, J. Geophys. Res., 95, 8617-8638.

Rabinowicz, E., 1956, Autocorrelation analysis of the sliding process, J. Appl. Phys., 27, 131-135.

RuinA, A. L., 1983, Slip instability and state variable friction laws, J. Geophys. Res., 88, 10359-10370.

Sayles, R. S. and T. R. Thomas, 1979, Measurements of the statistical microgeometry of engineering surfaces, J. Lubr. Tech., 101, 409-418.

Timoshenko, S. and J. N. Goodier, 1951, Theory of elasticity, McGraw-Hill, New York.
Yamada, K., N. TAKedA, J. Kagami and T. NAor, 1978a, Surface density of asperities and real distribution of asperity heights on rubbed surfaces, Wear, 47, 5-20.

Yamada, K., N. Takeda, J. Kagami and T. NaOI, $1978 \mathrm{~b}$, Mechanism of elastic contact and friction between rough surfaces, Wear, 48, 15-34.

YosнiokA, N., 1994a, Elastic behavior of contacting surfaces under normal loads: A computer simulation using three-dimensional surface topographies, J. Geophys. Res., 99, 15549-15560.

Yosнiok a, N., 1994b, The role of plastic deformation in normal loading and unloading cycles, J. Geophys. Res., 99, 15561-15568.

Yoshioka, N. and M. KıкUCHI, 1993, Visco-elastic response of joints to transmission waves, Geophys. Res. Lett., 20, 1143-1146.

Yoshioka, N. and C. H. Scholz, 1989a, Elastic properties of contacting surfaces under normal and shear loads: Theory, J. Geophys. Res., 94, 1768117690.

Yoshioka, N. and C. H. Scholz, 1989b, Elastic properties of contacting surfaces under normal and shear loads: Comparison of theory with experiment, J. Geophys. Res., 94, 17691-17700. 